\title{
PERAN BRAND IMAGE DALAM MEMEDIASI PENGARUH COUNTRY OF ORIGIN TERHADAP NIAT BELI
}

\author{
Gusti Ngurah Gunawan' \\ I Putu Gde Sukaatmadja ${ }^{2}$
}

\author{
${ }^{1,2}$ Fakultas Ekonomi dan Bisnis Universitas Udayana (Unud), Bali, Indonesia \\ e-mail: gunawan.ngurah@yahoo.co.id
}

\begin{abstract}
ABSTRAK
Tujuan penelitian ini adalah untuk menguji peran brand image dalam memediasi pengaruh country of origin terhadap niat beli motor Vespa Piaggio di kota Denpasar. Metode yang digunakan untuk menentukan sampel adalah non-probability berbentuk purposive sampling dengan ukuran sampel sebanyak 120 orang responden. Pengumpulan data dilakukan dengan penyebaran kuesioner secara langsung di Kota Denpasar. Teknik analisis yang digunakan adalah analisis jalur (path analysis) dan uji sobel. Temuan penelitian menunjukkan bahwa terdapat hubungan yang positif dan signifikan antara country of origin terhadap brand image, hubungan yang positif dan singnifikan antara country of origin terhadap niat beli serta brand image mampu memediasi hubungan antara terhadap niat beli konsumen pada motor merek Vespa Piaggio di Kota Denpasar. Hasil tersebut berarti semakin baik citra negara asal merek serta semakin kuat brand image yang tertanam di benak konsumen, akan berpengaruh terhadap niat beli mereka akan suatu produk.
\end{abstract}

Kata kunci: country of origin, brand image, niat beli

\begin{abstract}
The purpose of this study is to test the role of brand image in mediating the influence of country of origin on the intention to buy a motor Vespa Piaggio in the city of Denpasar. The method used to determine the sample is non-probability in the form of purposive sampling with sample size of 120 respondents. Data collection was done by distributing questionnaires directly in Denpasar City.. The research findings show that there is a positive and significant correlation between country of origin to brand image, positive and significant relationship between country of origin to purchase intention and brand image able to mediate relationship between consumer purchase intention on Vespa Piaggio brand motor in Denpasar city. The result means the better the image of the home country of the brand and the stronger the brand image embedded in the minds of consumers, will affect their purchase intention of a product.
\end{abstract}

Keywords: country of origin, brand image, purchase intention 


\section{PENDAHULUAN}

Dewasa ini kebutuhan masyarakat akan sarana transportasi yang menunjang aktivitas sehari-hari mereka semakin meningkat. Salah satunya sarana transportasi paling banyak dan sering digunakan oleh masyarakat Indonesia yakni sepeda motor. Sepeda motor sangat efektif dan efisien digunakan di Indonesia karena, masyarakat akan lebih cepat di dalam mencapai tempat tujuan. Mengingat kini di kota besar Indonesia sudah semakin sesak dikarenakan banyaknya, baik penggunaan kendaraan pribadi maupun kendaraan umum. Peran sepeda motor disini sangat penting digunakan di Indonesia sebagai alat transportasi pribadi.

Berkembangnya industri otomotif di Indonesia menunjukkan persaingan yang semakin ketat, hal ini terlihat di mana perusahaan bersaing dan berlombalomba untuk menawarkan produk yang mereka miliki dengan berbagai model dan tipe, serta keunikan lain yang menjadi suatu ciri khas dari sepeda motor yang mereka miliki dengan harga yang sangat bersaing. Banyaknya pilihan yang diberikan oleh produsen sepeda motor di Indonesia membuat konsumen harus lebih hati-hati dan teliti di dalam menentukan pilihan mereka yang nantinya akan mendorong minat konsumen untuk membeli dan menggunakannya. Kehidupan masyarakat yang semakin sibuk dengan aktivitas menjadikan alat transportasi ini sangat penting digunakan dalam melakukan kegiatan sehari-hari. Jenis sepeda motor yang digandrungi masyarakat di Indonesia yaitu sepeda motor matic, karena sepeda motor matic memiliki keunggulan yang ditawarkan seperti tidak adanya transmisi manual, mengoperasikannya cukup mengatur gas dan rem saja tidak perlu mengoper-oper gigi apalagi mengatur kopling. Sepeda motor matic juga 
mensegmen semua kalangan baik laki-laki maupun perempuan, sepeda motor matic yang telah sejak lama beredar di pasaran Indonesia adalah sepeda motor Vespa Piaggio.

Vespa Piaggio merek sepeda motor yang ikut meramaikan pasar sepeda motor di Indonesia mengutamakan brand image mereka sebagai yang ditujukan bagi kelompok konsumen menengah ke atas yang membeli sepeda motor bukan hanya atas dasar fungsinya sebagai alat transportasi, melainkan juga lebih untuk memenuhi gaya hidup. Kemunculan sepeda motor Vespa Piaggio telah menjadi fenomena dalam masyarakat Indonesia terutamanya di kota Denpasar dimana tampilan New Vespa Piaggio keluaran tahun 2012 ke atas memiliki desain yang modern dengan teknologi yang baru, citra yang telah dibentuk oleh Vespa Piaggio sebagai kendaraan yang mempunyai prestise tinggi telah berhasil membuat konsumen menjadi loyal dalam menggunakan produk ini meskipun harus mengeluarkan uang yang tidak sedikit.

Vespa Piaggio terus mengupayakan inovasi tanpa mengurangi esensi dalam produknya untuk menghadapi persaingan ini. Situasi persaingan ketat maka keberadaan merek menjadi sangat penting karena merek merupakan representasi nilai yang ditawarkan sebuah produk kepada konsumen. Terdapat pertimbangan lain yang sering digunakan konsumen yaitu tentang negara asal produk tersebut, sebelum menentukan produk apa yang akan dibeli, untuk sebagian konsumen akan melihat darimana negara asal produk tersebut. Mengingat banyaknya variasi dan fitur-fitur yang ditawarkan oleh produsen sepeda motor di Indonesia untuk memenuhi selera konsumen yang beragam, membuat masyarakat Indonesia pada 
umumnya memilih sepeda motor sebagai sarana transportasi mereka. Namun, masyarakat Indonesia tentunya memiliki banyak pertimbangan dalam memilih produk sepeda motor jenis mana yang paling memenuhi baik kebutuhannya maupun keinginannya. Mengetahui tingginya minat masyarakat Indonesia dalam menggunakan sepeda motor sebagai kendaraan pribadi, membuat perusahaanperusahaan besar di bidang industri otomotif memproduksi sepeda motor dengan berbagai macam model, fitur, dan harga yang bersaing. Perusahaan yang bergerak di industri otomotif khususnya di Indonesia dikuasai oleh berbagai produsen otomotif besar dari mancanegara seperti Honda, Yamaha, Suzuki, Kawasaki yang berasal dari Jepang, TVS yang berasal dari India, Vespa dan Ducati yang berasal dari Italia.

Country of origin atau negara asal suatu produk merupakan informasi ekstrinsik yang sering digunakan oleh konsumen ketika mengevaluasi suatu produk (Tati dkk., 2015). Country of origin suatu produk akan menimbulkan persepsi kualitas akan baik buruknya produk tersebut. (Yanthi dan Jatra, 2015). Country of origin memainkan peran penting dalam persepsi konsumen terhadap produk dan merek dari negara tertentu (Hanzaee dan Khosrozadeh, 2011). Semakin baik citra negara dimana produk tersebut berasal, semakin baik pula persepsi konsumen terhadap produk tersebut. Menurut (Rezvani, 2012) konsumen memiliki banyak pertimbangan ketika konsumen ingin mengevaluasi produk sebelum melakukan pembelian, seperti merek, warna, dan desain. Country of origin sebagai evaluasi penting bagi konsumen karena evaluasi konsumen pada produk tidak hanya berdasarkan merek, warna, dan desain produk tetapi juga berdasarkan negara mana 
yang menghasilkan produk, bagaimana produk tersebut diproduksi dan siapa yang membuat produk.

Dasar penilaian konsumen berdasarkan negara asal produksinya tidak semata-mata melupakan penilaian konsumen terhadap produk itu sendiri dengan mengesampingkan negara asal produksinya. Konsumen dapat menilai melalui brand image produk tersebut. Definisi brand image menurut Kotler and Keller (2015) adalah persepsi yang dimiliki oleh konsumen saat pertama kali mendengar slogan yang diingat dan tertanam di benak konsumen. Konsumen biasanya bingung ketika mereka menghadapi produk sejenis di pasar. Waktu yang terbatas untuk mencari suatu informasi membuat mereka memiliki informasi yang terbatas sebagai dasar untuk memilih produk (Tulipa dan Muljani, 2015). Persepsi yang positif dan kepercayaan konsumen terhadap suatu merek akan menciptakan brand image yang baik. Oleh karena itu perusahaan harus dapat menciptakan suatu merek yang menarik dan menggambarkan manfaat produk yang sesuai dengan keinginan konsumen sehingga konsumen memiliki persepsi yang positif terhadap merek tersebut (Alma, 2009:37).

Para peneliti telah mengembangkan konsep tiga jenis brand image yaitu fungsional, simbolis, dan pengalaman (Chih et al., 2013). Peranan brand image penting karena memberikan kontribusi pada konsumen dalam memutuskan pilihan terhadap suatu merek tertentu. Merek yang baik juga menjadi dasar untuk membangun citra perusahaan yang positif dan mempengaruhi konsumen dalam melakukan pemilihan pembelian (Maunaza, 2012). Konsumen seringkali membentuk preferensi terhadap salah satu merek atau perusahaan dikarenakan 
imagenya, sedangkan dari preferensi itulah konsumen akan menentukan minatnya untuk membeli suatu produk atau tidak. Proses pemikiran dan pembelajaran yang dilakukan oleh konsumen dapat membentuk perilaku minat beli. Semakin baik brand image yang dibentuk perusahaan, maka minat beli konsumen juga akan mengalami peningkatan, sehingga brand image memiliki pengaruh yang signifikan terhadap niat beli konsumen terhadap suatu produk (Ambarwati dkk., 2015)

Pertimbangan tentang penggunaan country of origin dan brand image oleh konsumen memiliki tujuan untuk meningkatkan minat beli, dimana niat beli menurut (Tati dkk., 2015) dapat diartikan sebagai bentuk pikiran nyata dari rencana konsumen untuk membeli produk dalam jumlah tertentu dari beberapa merek yang tersedia dalam situasi tertentu. Minat beli timbul karena adanya rangsangan yang berasal dari dalam diri konsumen dan memberikan dorongan atau motivasi untuk memiliki suatu produk. Minat beli konsumen yang tinggi akan mendorong konsumen untuk melakukan pembelian. Sebaliknya, minat beli konsumen yang rendah dapat mengurangi kemungkinan terjadinya keputusan konsumen untuk membeli produk (Tati dkk., 2015)

Perilaku Konsumen adalah proses dan aktivitas ketika seseorang berhubungan dengan pencarian, pemilihan, pembelian, penggunaan, serta pengevaluasian produk dan jasa demi memenuhi kebutuhan dan keinginan. Segala aktivitas manusia pada umumnya pun tidak akan lepas dari transaksi jual-beli entah dari hanya berniat memilih, ataupun keinginan untuk membeli suatu poduk jasa yang didorong oleh suatu keadaan tertentu, baik dari lingkungan maupun dari pribadi sendiri (Solomon, 2007:4). Perilaku konsumen terjadi karena didasari oleh 
motif tertentu. Setiap tindakan konsumen dilakukan untuk mencapai tujuan yaitu memuaskan suatu kebutuhan dan atau keinginan. Motivasi sering kali tersembunyi dan tak dapat diobservasi. Dalam hal ini, keberadaan teori sangat berguna untuk membantu memahami motif apa yang mendorong seseorang untuk berperilaku tertentu. Riset perilaku konsumen sangat membantu untuk mengukur hal itu (Suprapti, 2010:3).

Perilaku konsumen dipengaruhi oleh faktor-faktor internal dan eksternal. Artinya, adalah bahwa perilaku konsumen baik konsumen individu maupun konsumen organisasi, dipengaruhi oleh faktor di dalam dirinya (Seperti persepsi, pembelajaran, kepribadian, dan sikap) dan oleh faktor di luar dirinya atau faktor lingkungan (seperti faktor situasi, kelompok referensi, keluarga, dan lingkungan pemasaran).

Negara asal atau biasa disebut dengan country of origin merupakan cerminan atau bayangan mental dari sebuah produk negara tertentu. Salah satu efek yang dimiliki oleh country of origin terhadap calon konsumen adalah seringkali calon konsumen beranggapan bahwa perusahaan atau merek tertentu berafiliasi dengan negara tertentu. (Dinata et al., 2015). Menurut (Stoenescu, 2015) terdapat dua variabel yang menonjol dalam hubungan antara country of origin dan minat beli konsumen, yaitu patriotism dan kefamilieran akan citra suatu negara, kefamilieran citra suatu negara memberikan kesan kepada konsumen bahwa mereka dapat mengandalkan country of origin sebagai jaminan akan kualitas suatu produk yang berdasarkan pengalaman masa lalu mereka, sedangkan patriotism dapat 
dihubungkan dengan sikap etnosentris konsumen, seperti kecenderungan konsumen dalam memilih produk yang berasal dari dalam negeri.

Menurut Hamzoi dan Meruka (2006) dalam Tati et al. (2015) mendefinisikan country of origin sebagai unit persepsi yang mencakup berbagai asosiasi negara, seperti pengetahuan atau pemikiran mereka mengenai karakteristik suatu negara, rakyatnya, kebiasaan dan perilaku mereka serta produk-produk terkait. Suria et al. (2016) mendefinisikan country of origin sebagai sebuah gambaran, reputasi, serta pandangan yang dibawa oleh pebisnis dan konsumen terhadap suatu negara.

Menurut Torres dan Gutierrez (2007) dalam Moksaoka (2006), Country of origin juga diberi label dengan nama lain seperti Country of Manufacture, Country of Assembly, dan Country of Design, dalam semua isu memiliki kekuatan untuk meninjau data tentang produk dan perilaku pembelian konsumen, sebagai hasilnya konsumen berpikir tentang negara yang berbeda sesuai dengan kesadaran dan keyakinan mereka, sehingga mereka menganggap pembelian mereka akan berdampak pada hal ini, sehingga country of origin dapat disimpulkan sebagai pandangan dari konsumen akan produk dari suatu negara dimana persepsi tersebut akan membentuk nilai baik atau buruknya suatu produk berdasarkan dari latar belakang negara yang memproduksi produk tersebut.

Brand Image merupakan representasi dari keseluruhan persepsi terhadap merek yang dibentuk oleh informasi dan pengalaman masa lalu terhadap merek itu. Citra terhadap merek berhubungan dengan sikap yang berupa keyakinan dan preferensi terhadap suatu merek. Konsumen yang memiliki citra yang positif 
terhadap suatu merek, akan lebih memungkinkan untuk melakukan suatu pembelian (Setiadi, 2003 dalam Evelina et al., 2012). Rizan et al. (2012) mengemukakan bahwa brand image adalah anggapan tentang merek yang direfleksikan konsumen yang perpegang pada ingatan konsumen.

Untuk memenuhi kebutuhan konsumen untuk berbagai macam jenis produk, suatu bisnis menganggap bahwa merek memiliki makna yang unik. Menurut Hogan dalam Ratri (2007), citra merek merupakan asosiasi dari informasi yang tersedia mengenai produk, jasa, dan perusahaan dari merek yang dimaksud. Informasi ini didapat dari dua cara, yang pertama, melalui persepsi yang di bentuk oleh perusahaan dari merek tersebut melalui berbagai macam bentuk komunikasi, seperti promosi, iklan, logo, hubungan masyarakat, fasilitas retail, sikap karyawan dalam melayani penjualan, dan performa pelayanan. Kedua, pengalaman konsumen secara langsung, yang terdiri dari kepuasan fungsional dan kepuasan emosional. Sehingga suatu merek selain dapat memeberikan kualitas yang baik sesuai yang dijanjikan juga haru dapat memahami apa kebutuhan konsumen serta memberikan suatu nilai yang lebih bagi konsumen.

Brand image menjadi salah satu daya tarik konsumen terhadap produk, maka perusahaan haruslah membangun brand image yang positif dimata konsumen, yang nantinya akan meningkatkan keinginan konsumen untuk membeli suatu produk.

Menurut Kotler and Armstrong (2015), minat adalah kecenderungan seseorang dalam memilih layanan atau produk. Purchase intention atau minat pembelian adalah kemungkinan konsumen melakukan pembelian layanan atau produk sesuai dengan harga yang ditawarkan oleh penyedia layanan atau produk 
(Olson and Paul, 2014). Menurut Schifmann dan Kanuk (2008:201) menyatakan minat adalah salah satu aspek dari psikologis seseorang dan memiliki pengaruh cukup besar terhadap sikap perilaku. Minat beli dipengaruhi oleh dua faktor yakni faktor internal dan faktor eksternal. Internal diri konsumen, yang berupa motivasi, persepsi, perasaan dan emosinya merupakan faktor internal. Sedangkan, hal-hal usaha pemasaran dan faktor sosial budaya merupakan faktor eksternal. (Dinata dkk., 2015)

Pengalaman adalah peristiwa penting bagi konsumen seperti yang diungkapkan Tetanoe and Dharmayanti (2014) sehingga konsumen yang mendapatkan layanan dan pengalaman yang baik setelah menggunakan layanan atau produk akan menciptakan kepuasan bagi konsumen tersebut (Rangkuti, 2015) diperkuat dengan penelitian Hijir (2015), maka selanjutnya konsumen yang puas menciptakan minat membeli layanan tersebut (Olson and Paul, 2014) dan hal ini menguntungkan perusahaan penyedia layanan atau produk tersebut (Nasermoadeli, Ling, and Maghnati, 2013). Niat beli sebagai kecenderungan seorang konsumen untuk mengambil tindakan yang berhubungan dengan pembelian layanan atau produk tertentu dan akan selalu mencari informasi tentang layanan atau produk yang diinginkan sebelum memutuskan untuk melakukan pembelian pelayanan atau produk tersebut (Banjarnahor, 2017). Selanjutnya, konsumen akan mengevaluasi produk atau layanan jasa dalam merek tersebut. Minat beli tidak selalu berdampak pada tahap pembelian pada saat itu juga (langsung).

Country of origin menimbulkan persepsi di benak konsumen, produk yang berasal dari negara tertentu yang memiliki citra yang baik, akan memberikan suatu 
kesan di mata konsumen. Citra negara yang baik akan mempengaruhi brand image dari suatu produk, semakin baik citra negara asal produk, brand image yang tercipta juga semakin baik.

Penelitian yang dilakukan Permana dan Haryanto (2014) menemukan bahwa country of origin berpengaruh secara signifikan terhadap brand image. Menurut penelitian yang dilakukan Tulipa dan Muljani (2015) mengatakan bahwa country of origin memiliki pengaruh yang signifikan terhadap brand image. Hal ini sejalan dengan penelitian Ahasanul et al. (2015) menemukan bahwa country of origin membawa pengaruh yang positif dan signifikan terhadap brand image, hal ini juga didukung oleh penelitian Diamantopoulus et al. (2011) berpendapat bahwa country of origin memiliki pengaruh yang positif dan signifikan terhadap brand image. Sehingga semakin baik citra dari suatu negara yang menghasilkan produk atau country image, akan berdampak positif juga terhadap citra dari merek tersebut atau brand image.

$\mathrm{H}_{1}$ : Country of origin berpengaruh positif dan signifikan terhadap brand image.

Country of origin dapat berdampak baik dampak positif maupun berdampak negatif terhadap niat beli konsumen. Citra country of origin yang dipersepsikan positif dapat menyebabkan atau menimbulkan keinginan atau minat konsumen untuk membeli suatu produk yang mana nantinya akan berakhir pada pembelian produk. Sebaliknya, apabila citra country of origin yang dipersepsikan negatif memiliki potensi untuk mengurangi minat konsumen untuk membeli suatu produk sehingga kemungkinan suatu produk untuk menjadi pilihan seorang konsumen pun berkurang. 
Oleh karena itu, citra country of origin juga dianggap memiliki peran penting dalam memengaruhi minat pembelian konsumen (Tati dkk., 2015). Penelitian yang dilakukan Dinata dkk. (2015) menjelaskan bahwa secara signifikan variabel country of origin berpengaruh positif terhadap minat beli seorang calon konsumen yang ingin membeli iPad di Indonesia. Penelitian Yunus dan Wan (2015) menyebutkan bahwa country of origin secara positif akan mempengaruhi niat beli konsumen. Hal ini sejalan dengan penelitian Hanzaee dan Khosrozadeh (2011) menemukan bahwa niat beli dipengaruhi secara positif dan signifikan oleh country of origin.

$\mathrm{H}_{2}$ : Country of origin berpengaruh positif dan signifikan terhadap niat beli.

Seringkali konsumen membentuk preferensi terhadap merek atau perusahaan dikarenakan imagenya, sedangkan preferensi itulah konsumen akan menentukan niatnya untuk membeli atau tidaknya suatu produk tertentu. Penelitian Chih et al. (2013) menyatakan bahwa brand image berpengaruh positif terhadap niat beli. Hal ini juga didukung oleh penelitian Ambarwati dkk. (2015) yang berpendapat bahwa brand image berpengaruh signifikan terhadap minat beli konsumen. Penelitian yang dilakukan oleh Maunaza (2012) menemukan bahwa brand image memiliki pengaruh positif dan signifikan terhadap minat beli konsumen. Brand image mempengaruhi minat beli konsumen sebesar $33.1 \%$ dan sisanya sebesar $66.9 \%$ dipengaruhi oleh faktor lain. Maka dapat dijelaskan bahwa semakin baik image yang dimiliki oleh suatu brand tertentu, akan meningkatkan niat beli konsumen terhadap produk tersebut. Sebaliknya apabila image yang ditonjolkan oleh suatu brand kurang baik, hal tersebut nantinya akan mengurangi atau menurunkan niat 
konsumen untuk membeli produk tersebut.

$\mathrm{H}_{3}$ : Brand image berpengaruh positif dan signifikan terhadap niat beli.

Penelitian yang dilakukan Ahasanul et al. (2015) menunjukkan bahwa country of origin pengaruhnya terhadap niat beli adalah melalui brand image sebagai variabel mediasi. Penelitian ini sejalan dengan penelitian Diamantopoulos et al. (2011) yang berpendapat bahwa image country of origin berpengaruh secara tidak langsung terhadap niat beli konsumen, dan dalam pengaruhnya sepenuhnya dimediasi oleh brand image. Penelitian Bhakar et al. (2013) menyatakan bahwa country of origin akan berdampak tidak signifikan terhadap purchase intention apabila hubungan terjadi secara langsung. Namun perbedaan terjadi ketika country of origin diterapkan bersamaan dengan brand image terhadap purchase intention maka hasil yang dinyatakan oleh Bhakar akan positif dan signifikan.

$\mathrm{H}_{4}$ : Peran brand image memediasi pengaruh country of origin terhadap niat beli

\section{METODE PENELITIAN}

Penelitian ini dilakukan di wilayah Kota Denpasar. Lokasi ini dipilih karena Kota Denpasar merupakan pusat kota dari Provinsi Bali yang tingkat pendapatan per kapita penduduknya yaitu 18.681.146.599 tertinggi No 2 di Bali di bawah Kabupaten Badung yang terdiri atas beragam penduduk, serta pertumbuhan ekonomi di Denpasar yang cukup tinggi dan didukung daya beli masyarakat yang cukup tinggi untuk dapat membeli sepeda motor Vespa Piaggio.

Obyek penelitian ini adalah perilaku konsumen, pengaruh country of origin (X) terhadap niat beli $(\mathrm{Y})$, pengaruh country of origin $(\mathrm{X})$ terhadap brand image $(\mathrm{M})$, pengaruh brand image $(\mathrm{M})$ terhadap niat beli $(\mathrm{Y})$, serta peran brand image 
(M) dalam memediasi pengaruh country of origin (X) terhadap niat beli (Y).

Tabel 1.

\section{Indikator Variabel}

\begin{tabular}{|c|c|c|c|c|c|}
\hline Variabel & No & Variabel & & Indikator & Sumber \\
\hline & 1 & $\begin{array}{c}\text { Country of } \\
\text { Origin } \\
\left(\mathrm{X}_{1}\right)\end{array}$ & a) & $\begin{array}{l}\text { Inovasi negara asal merek } \\
\text { dalam berproduksi }\left(\mathrm{X}_{1.1}\right) \\
\text { Tingkat kemajuan teknologi } \\
\text { negara asal merek }\left(\mathrm{X}_{1.2}\right) \\
\text { Citra negara asal merek } \\
\text { sebagai negara maju }\left(\mathrm{X}_{1.3}\right) \\
\text { Prestise yang dimiliki negara } \\
\text { asal merek }\left(\mathrm{X}_{1.4}\right)\end{array}$ & $\begin{array}{l}\text { Permana dan } \\
\text { Haryanto } \\
\text { (2015) dan } \\
\text { Tulipa dan } \\
\text { Muljani } \\
\text { (2015) }\end{array}$ \\
\hline \multicolumn{6}{|l|}{ Eksogen } \\
\hline Mediasi & 2 & $\begin{array}{l}\text { Brand Image } \\
\qquad\left(\mathrm{M}_{1}\right)\end{array}$ & $\begin{array}{l}\text { a) } \\
\text { b) } \\
\text { c) }\end{array}$ & $\begin{array}{l}\text { Citra Perusahaan }\left(\mathrm{M}_{1.1}\right) \\
\text { Citra Produk }\left(\mathrm{M}_{1.2}\right) \\
\text { Reputasi Merek }\left(\mathrm{M}_{1.3}\right)\end{array}$ & $\begin{array}{l}\text { Ambarwati } \\
\text { dkk. (2015) } \\
\text { dan } \\
\text { Ahasanul et } \\
\text { al. (2015) }\end{array}$ \\
\hline Endogen & 3 & $\begin{array}{c}\text { Niat Beli } \\
\left(\mathrm{Y}_{1}\right)\end{array}$ & a) & $\begin{array}{l}\text { Perhatian konsumen terhadap } \\
\text { keberadaan produk }\left(\mathrm{Y}_{1.1}\right) \\
\text { Ketertarikan akan suatu } \\
\text { produk }\left(\mathrm{Y}_{1.2}\right) \\
\text { Ingin mengetahui lebih lanjut } \\
\text { tentang produk }\left(\mathrm{Y}_{1.3}\right) \\
\text { Keinginan untuk memiliki } \\
\text { produk }\left(\mathrm{Y}_{1.4}\right) \\
\text { Mempertimbangkan untuk } \\
\text { membeli produk }\left(\mathrm{Y}_{1.3}\right)\end{array}$ & $\begin{array}{l}\text { Schifmann } \\
\text { dan Kanuk } \\
\text { (2008) dan } \\
\text { Tati dkk. } \\
\text { (2015) }\end{array}$ \\
\hline
\end{tabular}

Sumber: Data diolah, 2018

Data kuantitatif yang digunakan dalam penelitian ini adalah tabulasi hasil kuesioner yang telah dijawab oleh responden, umur, pekerjaan responden. Data kualitatif pada penelitian ini berupa gambaran umum tentang produk sepeda motor merek Vespa Piaggio dan pendapat responden terhadap pernyataan yang ada di dalam kuesioner. Sumber primer adalah responden yang langsung memberikan tanggapan terhadap variabel - variabel penelitian yang akan diuji. Sumber sekunder dalam penelitian ini adalah berita - berita online yang terkait dengan sepeda motor merek Vespa Piaggio, dan studi - studi empiris yang berkaitan dengan variabel country of origin, brand image, dan niat beli produk sepeda motor merek Vespa 
Piaggio.

Populasi yang digunakan pada penelitian ini adalah konsumen yang belum pernah melakukan pembelian produk sepeda motor merek Vespa Piaggio di Denpasar dengan jumlah populasi yang tidak diketahui secara pasti (infinite). Penentuan sampel penelitian ini menggunakan metode non - probability sampling yakni teknik pengambilan sampel yang tidak memberi peluang / kesempatan yang sama bagi setiap unsur atau anggota populasi untuk dipilih menjadi sampel (Rahyuda dkk., 2004). Teknik non probability sampling yang dipilih adalah purposive sampling yaitu teknik penentuan sampel dengan pertimbangan kriteria tertentu. Untuk memperoleh data yang valid, maka jumlah sampel responden yang diambil paling sedikit 5-10 kali jumlah indikator (Sugiyono, 2013;130). Perhitungan ukuran sampel responden yang diuji adalah sebagai berikut :

$$
\begin{aligned}
\text { Jumlah Responden } & =12 \times 10 \\
& =12 \text { indikator } \times 10 \\
& =120 \text { responden }
\end{aligned}
$$

Metode pengumpulan data untuk penelitian ini adalah dengan menggunakan metode survey yakni dengan kuesioner. Kuesioner di sebarkan di Kota Denpasar dan pengisiannya di dampingi oleh peneliti. Pengukuran atas jawaban dari responden diukur dengan menggunakan skala Likert. Teknik analisis data yang digunakan dalam penelitian ini adalah teknik analisis jalur (path analysis). Teknik analisis jalur ini dapat didefinisikan sebagai perluasan dari analisis linier berganda dalam memperkirakan hubungan kausalitas antara yang telah ditetapkan berdasarkan teori. Analisis jalur digunakan untuk menentukan hubungan 3 variabel 
atau lebih dalam mengkorfimasi dan menolak hipotesis.

Analisis jalur digunakan untuk menganalisis pola hubungan antar variabel dengan tujuan untuk mengetahui pengaruh langsung maupun tidak langsung variabel eksogen terhadap variabel endogen. Dasar perhitungan koefisian jalur adalah analisis korelasi dan regresi dan dalam perhitungannya menggunakan software dengan program SPSS for windows. (Riduwan dan Kuncoro, 2011:2).

Uji Sobel dilakukan untuk menguji peran mediasi yang diberikan oleh variabel brand image, maka pengujian signifikansi variabel mediasi dalam model dapat diperiksa dari hasil uji pengaruh tidak langsung. Berdasarkan pengujian ini dapat diteliti tingkat intervensi dari variabel mediasi apakah memediasi penuh ( full mediation) atau memediasi sebagian (partial mediation) atau bukan mediasi.

\section{HASIL PENELITIAN DAN PEMBAHASAN}

Sebagaian besar responden berada pada klasifikasi usia 17 - 21 tahun dengan persentase sebesar 46,7 persen dari total responden yang digunakan. Selanjutnya posisi kedua terbesar ialah responden dengan rentang usia 27-31 tahun, sebesar 28,3 persen, dilanjutkan dengan rentang usia 22-26 sebanyak 15,8 persen, dilanjutkan dengan rentang usia 32-36, sebesar 5,8 persen dan pada posisi terakhir yaitu rentang usia > 37 sebesar 3,7 persen. Penelitian ini seluruhnya adalah reponden berjenis kelamin laki-laki yang dengan persentase 68,3 dan perempuan dengan persentase 31,7. Berdasarkan pekerjaan, menunjukkan bahwa mayoritas responden jenis pekerjaan adalah Pelajar/Mahasiswa sebesar 61,7 persen dari total keseluruhan responden. Posisi kedua ditempati oleh reponden dengan jenis pekerjaan Karyawan Swasta sebesar 24,7 persen, diikuti oleh responden dengan jenis pekerjaan 
Pengusaha/Wiraswasta sebesar 10 persen dan posisi terakhir yaitu responden dengan jenis pekerjaan PNS sebesar 4,7 persen.

Analisis untuk dapat menyusun persamaan struktural yang digunakan, maka terlebih dahulu data yang diperoleh diolah dan dihitung menggunakan program SPSS sehingga diperoleh hasil analisis seperti pada Tabel 2. dan 3.

Tabel 2.

Hasil Analisis Jalur Persamaan Regresi 1

\begin{tabular}{|c|c|c|c|c|c|c|}
\hline & \multirow{2}{*}{ Model } & \multicolumn{2}{|c|}{ Unstandardized Coefficients } & \multirow{2}{*}{$\begin{array}{c}\text { Standardized } \\
\text { Coefficients } \\
\text { Beta } \\
\end{array}$} & \multirow{2}{*}{$\begin{array}{c}\mathbf{t} \\
\text { hitung }\end{array}$} & \multirow{2}{*}{ Sig. } \\
\hline & & B & Std. Error & & & \\
\hline \multirow[t]{2}{*}{1} & (Constant) & 7,559 & 1,076 & \multirow{2}{*}{0,390} & 7,025 & 0,000 \\
\hline & $\begin{array}{l}\text { Country of } \\
\text { Origin }\end{array}$ & 0,299 & 0,65 & & 4,597 & 0,000 \\
\hline $\mathrm{R} 1^{2}:$ & 0,152 & F Statistik : 21,131 & Sig & 00 & & \\
\hline
\end{tabular}

Berdasarkan hasil analisis jalur substruktur 1 seperti yang disajikan pada tabel tersebut, maka persamaan strukturalnya adalah sebagai berikut:

$$
\begin{aligned}
& \mathrm{M}=\beta_{1} \mathrm{X}+\mathrm{e}_{1} \ldots \\
& \mathrm{M}=0,390 \mathrm{X}+\mathrm{e}_{1}
\end{aligned}
$$

Tabel 3.

\begin{tabular}{|c|c|c|c|c|c|}
\hline \multirow{2}{*}{ Model } & \multicolumn{2}{|c|}{ Unstandardized Coefficients } & \multirow{2}{*}{$\begin{array}{c}\text { Standardized } \\
\text { Coefficients } \\
\text { Beta }\end{array}$} & \multirow{2}{*}{$\stackrel{\mathbf{t}}{\text { hitung }}$} & \multirow{2}{*}{ Sig. } \\
\hline & B & Std. Error & & & \\
\hline 1 (Constant) & 2,651 & 1,682 & & 1,576 & 0,118 \\
\hline Country of & 0562 & 0,093 & 0,492 & 6,054 & 0,000 \\
\hline Brand Image & 0,717 & 0,121 & 0,421 & 5,937 & 0,000 \\
\hline $\mathrm{R} 2^{2}: 0,461$ & \multicolumn{2}{|c|}{ F Statistik : 44,888} & $F: 0,000$ & & \\
\hline
\end{tabular}

Hasil Analisis Jalur Persamaan Regresi 2

Sumber: Data diolah, 2018

Berdasarkan hasil analisis jalur substruktur 2 seperti yang disajikan pada

Tabel 3 tersebut, maka persamaan strukturalnya adalah sebagai berikut: 
$\mathrm{Y}=\beta_{2} \mathrm{X}+\beta_{3} \mathrm{M}+\mathrm{e}_{2}$

$\mathrm{Y}=0,492 \mathrm{X}+0,421 \mathrm{M}+\mathrm{e}_{2}$

Berdasarkan model substruktur 1 dan substruktur 2, maka dapat disusun model diagram jalur akhir. Sebelum menyusun model diagram jalur akhir, terlebih dahulu dihitung nilai standar error sebagai berikut :

$$
\begin{aligned}
& \mathrm{e}=\sqrt{1-\mathrm{R} 1}^{2} \ldots \ldots \ldots \ldots \ldots \ldots \ldots \ldots \ldots \ldots \ldots \ldots \ldots \\
& \mathrm{e}_{1}={\sqrt{1-R 1^{2}}}^{2} \sqrt{1-0,152}=0,921 \\
& \mathrm{e} 2=\sqrt{1-R 2}^{2}=\sqrt{1-0,502}=0,709
\end{aligned}
$$

Berdasarkan perhitungan pengaruh error (e), didapatkan hasil pengaruh error $\left(\mathrm{e}_{1}\right)$ sebesar 0,921 dan pengaruh error $\left(\mathrm{e}_{2}\right)$ sebesar 0,709. Hasil koefisien determinasi total adalah sebagai berikut :

$$
\begin{aligned}
\mathrm{R}^{2} \mathrm{~m} & =1-\left(\mathrm{Pe}_{1}\right)^{2}\left(\mathrm{Pe}_{2}\right)^{2} \ldots \ldots \\
& =1-(0,921)^{2}(0,709)^{2} \\
& =1-(0,848)(0,503) \\
& =1-0,427=0,573
\end{aligned}
$$

Nilai determinasi total sebesar 0,573 mempunyai arti bahwa sebesar 57,3\% variasi niat beli dipengaruhi oleh variasi country of origin dan brand image, sedangkan sisanya sebesar $42,7 \%$ dijelaskan oleh faktor lain yang tidak dimasukkan ke dalam model.

Uji sobel dihitung dengan rumus dibawah ini:

$$
Z=\frac{\mathrm{a}}{\sqrt{\mathrm{b}^{2} s_{u}^{2}+u^{2} s_{b}^{2}+s_{u}^{2} s_{b}^{2}}}
$$

Keterangan:

$$
\begin{aligned}
& \mathrm{a}=0,390 \\
& \mathrm{~s}_{\mathrm{a}}=0,065 \\
& \mathrm{~b}=0,421
\end{aligned}
$$




$$
\begin{gathered}
\mathrm{sb}=0,121 \\
Z=\frac{0,390 \cdot 0,421}{\sqrt{0,421^{2} 0,065^{2}+0,390^{2} 0,121^{2}+0,065^{2} 0,121^{2}}} \\
Z=\frac{0,1642}{\sqrt{0,0007+0,0022+0,0001}} \\
Z=\frac{0,1642}{\sqrt{0,0030}} \\
Z=\frac{0,1777}{0,55114} \\
\mathbf{Z}=\mathbf{2 , 9 7 9 1}
\end{gathered}
$$

Tabel 4.

Hasil Uji Sobel

\begin{tabular}{cc}
\hline Nilai $\mathbf{Z}$ & Sig \\
\hline 2,9791 & 0,000 \\
\hline
\end{tabular}

Sumber: Data diolah, 2018

Berdasarkan hasil Uji Sobel pada Tabel 4 menunjukkan bahwa hasil tabulasi $\mathrm{Z}=2,9791>1,96$ dengan tingkat signifikan sebesar $0,000<0.05$ yang berarti $\mathrm{H}_{0}$ ditolak dan $\mathrm{H}_{1}$ diterima yang berarti variabel brand image dinilai secara signifikan memediasi variabel country of origin terhadap niat beli sepeda motor merek Vespa Piaggio di kota Denpasar.

Berdasarkan hasil analisis pengaruh country of origin terhadap brand image diperoleh nilai koefisien Beta sebesar 0,390 dengan tingkat signifikansi sebesar $0,000(\leq 0,05)$ yang berarti Ho ditolak dan $\mathrm{H}_{1}$ diterima. Hasil tersebut berarti bahwa variabel country of origin berpengaruh positif dan signifikan terhadap brand image. Jadi, semakin baik citra dari negara asal sepeda motor merek Vespa Piaggio, maka akan meningkatkan brand image produk sepeda motor merek Vespa Piaggio di Kota Denpasar. 
Hasil penelitian ini sejalan dengan hasil penelitian sebelumnya yang dilakukan oleh Permana dan Haryanto (2014) dan Tulipa dan Muljani (2015) yang menemukan bahwa country of origin memiliki pengaruh yang signifikan terhadap brand image. Serta sesuai dengan penelitian Diamantopoulus et al. (2011), dan Ahasanul et al. (2015) yang menyatakan bahwa country of origin berpengaruh secara positif dan signifikan terhadap brand image. Dapat disimpulkan bahwa country of origin memiliki pengaruh yang positif dan signifikan terhadap brand image, hal ini berarti bahwa dengan meningkatnya citra country of origin yang baik akan meningkatkan juga presepsi positif terkait brand image produk sepeda motor Vespa Piaggio.

Berdasarkan hasil analisis pengaruh country of origin terhadap niat beli diperoleh nilai koefisien Beta sebesar 0,429 dengan tingkat signifikansi sebesar $0,000(\leq 0,05)$ yang berarti Ho ditolak dan $\mathrm{H}_{1}$ diterima. Hasil tersebut berarti bahwa variabel country of origin berpengaruh positif dan signifikan terhadap niat beli. Ini berarti semakin positif persepsi tentang negara asal produk sepeda motor Vespa Piaggio akan meningkatkan niat beli sepeda motor motor Vespa Piaggio di Kota Denpasar.

Hasil penelitian ini mendukung temuan penelitian yang dilakukan Dinata dkk. (2015) menjelaskan bahwa secara signifikan variabel country of origin berpengaruh positif terhadap minat beli seorang calon konsumen. Yunus dan Wan (2016) menyebutkan bahwa country of origin secara positif akan memengaruhi niat beli konsumen. Menurut penelitian Hanzaee dan Khosrozadeh (2011) menemukan bahwa niat beli dipengaruhi secara positif dan signifikan oleh country of origin. Hal 
ini berarti bahwa country of origin memiliki pengaruh yang positif dan signifikan terhadap niat beli. Jadi, jika orang memiliki persepsi yang baik tentang negara asal merek sepeda motor merek Vespa Piaggio, maka akan meningkatkan niat beli mereka terhadap sepeda motor merek Vespa Piaggio di Kota Denpasar.

Berdasarkan hasil analisis pengaruh brand image terhadap niat beli diperoleh nilai koefisien Beta sebesar 0,421 dengan tingkat signifikansi sebesar 0,000 $(\leq 0,05)$ yang berarti Ho ditolak dan $\mathrm{H}_{1}$ diterima. Hasil tersebut berarti bahwa brand image berpengaruh positif dan signifikan terhadap niat beli. Hal ini berarti semakin baik citra merek yang dibangun oleh Vespa Piaggio terhadap produk sepeda motornya, akan semakin meningkatkan niat beli sepeda motor merek Vespa Piaggio di Kota Denpasar

Hasil penelitian ini mendukung penelitian Chih et al. (2013) yang menyatakan bahwa brand image berpengaruh positif terhadap niat beli. Hal ini juga didukung oleh penelitian Ambarwati dkk. (2015) yang berpendapat bahwa brand image berpengaruh signifikan terhadap minat beli konsumen. Penelitian oleh Maunaza (2012) menemukan bahwa brand image memiliki pengaruh positif dan signifikan terhadap minat beli konsumen. Dapat disimpulkan bahwa brand image memiliki pengaruh yang positif dan signifikan terhadap niat beli. Hal ini berarti ketika citra merek yang baik terkait sepeda motor merek Vespa Piaggio telah tertanam di benak masyarakat, maka niat beli masyarakat di Kota Denpasar terhadap sepeda motor merek Vespa Piaggio akan meningkat.

Pengujian hipotesis pada peran brand image dalam memediasi country of origin terhadap niat beli pada sepeda motor merek Vespa Piaggio di Kota Denpasar, 
dengan menggunakan Uji Sobel membuktikan peran brand image secara signifikan memediasi pengaruh country of origin terhadap niat beli produk sepeda motor Vespa Piaggio, dengan hasil $\mathrm{Z}=2,9791>1,96$ dengan tingkat signifikansi $0,000<$ 0,05 .

Hasil penelitian ini sejalan dengan penelitian yang dilakukan Ahasanul et al. (2015) menunjukkan bahwa country of origin pengaruhnya terhadap niat beli adalah melalui brand image sebagai variabel mediasi. Menurut Diamantopoulos et al. (2011) image country of origin berpengaruh secara tidak langsung terhadap niat beli konsumen, dan dalam pengaruhnya sepenuhnya dimediasi oleh brand image. Penelitian Bhakar et al. (2013) menyatakan ketika country of origin diterapkan bersamaan dengan brand image terhadap purchase intention maka hasil yang dinyatakan oleh Bhakar et al. (2013) akan positif dan signifikan.

Implikasi penelitian menekankan pada manfaat nyata dari hasil penelitian ini bagi pihak-pihak yang berkepentingan khususnya bagi perusahaan yaitu perusahaan produsen sepeda motor merek Vespa Piaggio. Perusahaan Vespa Piaggio sebaiknya mempertahankan citra country of origin yang baik dan brand image bagi produk yang ditawarkan. Terbukti dari hasil penelitian yang diperoleh dan pemaparan atas keterkaitan antar variabel yang secara umum memiliki pengaruh yang positif dan signifikan. Niat beli akan tercipta karena country of origin yang positif. Persepsi baik yang timbul terhadap country of origin sepeda motor merek Vespa Piaggio yaitu Italia, akan meningkatkan niat beli sepeda motor merek Vespa Piaggio. Perusahaan Vespa Piaggio harus tetap mempertahankan citra negara yang baik, 
serta terus melakukan inovasi dalam berproduksi terkait produk-produknya agar dapat bersaing dengan perusahaan-perusahaan lain.

Niat beli dapat meningkat karena persepsi country of origin yang baik serta brand image yang positif tertanam di benak konsumen. Perusahaan produsen Vespa Piaggio perlu mempertahankan citra negara asal yang baik serta menanamkan brand image yang baik, di mana brand image dapat menjembatani pengaruh antara country of origin dengan niat beli. Sehingga semakin baik citra negara dan semakin kuat brand image yang tertanam dibenak konsumen akan memengaruhi niat beli mereka terhadap sepeda motor merek Vespa Piaggio. Selain melalui brand image, niat beli juga dapat dipengarhi secara langsung oleh country of origin. Variabel yang diteliti memiliki keterkaitan satu sama lain sehingga Vespa Piaggio perlu memperhatikan persepsi tentang country of origin serta tetap menjaga brand image yang baik dimata konsumen sehingga niat beli mereka akan meningkat.

Patut disadari bahwa terdapat beberapa keterbatasan dari penelitian ini yang diantaranya: ruang lingkup penelitian terbatas pada wilayah Kota Denpasar, sehingga hasil penelitian ini tidak dapat digeneralisasi untuk konsumen di luar wilayah Kota Denpasar. Mengingat penelitian ini dilakukan dalam jangka waktu yang cukup singkat sedangkan lingkungan dapat berubah setiap saat, yang menyebabkan penelitian ini penting untuk dilakukan kembali di wilayah Kota Denpasar.

\section{SIMPULAN DAN SARAN}

Berdasarkan pembahasan hasil penelitian yang telah dilakukan, maka dapat disimpulkan bahwa country of origin berpengaruh positif dan signifikan terhadap 
niat beli. Hal ini berarti apabila semakin positif persepsi tentang negara asal sepeda motor merek Vespa Piaggio, maka akan meningkatkan niat membeli sepeda motor merek Vespa Piaggio di Kota Denpasar.

Country of origin berpengaruh positif dan signifikan terhadap brand image. Hal ini berarti semakin baik citra Negara Italia sebagai Negara asal merek sepeda motor merek Vespa Piaggio, maka akan meningkatkan citra merek dari sepeda motor merek Vespa Piaggio di Kota Denpasar.

Brand image berpengaruh positif dan signifikan terhadap niat beli. Hal ini berarti semakin baik citra merek yang dibangun produk sepeda motor Vespa Piaggio, maka akan meningkatkan niat pembelian sepeda motor merek Vespa Piaggio di Kota Denpasar.

Brand image mampu memediasi hubungan country of origin terhadap niat beli. Hal ini berarti bahwa brand image yang terbentuk pada sepeda motor merek Vespa Piaggio turut memengaruhi country of origin terhadap niat beli sepeda motor Vespa Piaggio di Kota Denpasar

Saran yang dapat diberikan berdasarkan kesimpulan yang didapat adalah sebaiknya pihak Vespa Piaggio lebih mengutamakan prestise atau kemampuan yang dimiliki negara asal agar lebih istimewa, sehingga akan meningkatkan minat calon konsumen untuk membeli produk sepeda motor Vespa Piaggio serta tetap menjaga loyalitas konsumen yang sudah menggunakan merek Vespa Piaggio.

Sebaiknya pihak Vespa Piaggio lebih membangun citra perusahaan yang baik terkait sepeda motor Vespa, misalnya dengan memfasilitasi komunitas-komunitas Vespa yang sudah ada, serta bisa mengadakan Corporate Social Responsibility 
(CSR) ke masyarakat sehingga Vespa Piaggio akan semakin dikenal masyarakat dan akan membentuk citra perusahaan yang baik di benak calon.

Sebaiknya pihak Vespa Piaggio lebih mempertimbangkan minat beli konsumen, seperti memberikan informasi dan melakukan promosi di wilayahwilayah tertentu agar lebih meyakinkan calon konsumen sepeda motor merek Vespa Piaggio yang nantinya dapat meningkatkan niat beli mereka.

Sebaiknya pihak Vespa Piaggio mempertahankan tingkat kemajuan teknologi di negara asalnya serta menjaga citra produk yang baik dimilki sepeda motor Vespa Piaggio agar dapat meningkatkan minat konsumen untuk membeli produk tersebut.

\section{REFERENSI}

Ahasanul Haque., Naila Anwar., Farzana Yasmin., Abdullah Sarwar., Zariyah Ibrahim., and Abdul Momen. 2015. Purchase Intention of Foreign Products: A Study on Bangladeshi Consumer Perspective. SAGE Open, 1-12

Ambarwati, Miki., Sunarti., dan Mukhammad Kholid Mawardi. 2015. Pengaruh Citra Merek Terhadap Minat Beli (Survei Pada Mahasiswa Universitas Brawijaya Yang Menggunakan Pasta Gigi Pepsodent). Jurnal Administrasi Bisnis (JAB), 25(1), pp: 1-7

Banjarnahor. J. 2017. Anteseden Customer Satisfacation dan Dampaknya pada Purchase Intention. Jurnal Manajemen dan Pemasaran Jasa. Universitas Trisakti. Vol. 10 No. 1 Maret 2017: 141-156

Bhakar, S. S., Shailja Bhakar., and Shilpa Bhakar. 2013. Relationship Between Country of Origin, Brand Image and Customer Purchase Intention. Far East Journal of Psychology and Business, 10(2), pp: 25-47.

Chih, C, Y., P. J. Lin and C. S Chen. 2013. How Brand Image, Country Of Origin, and Self, Congruity Influence Internet Users, Purchase Intention. Society For Research, 41(4), pp: 599-612.

Diamantopulos, Bodo Schlegelmilch, Dayananda Palihawadana. 2011. The relationship between country of origin image and brand image as drivers of purchase intention, International Marketing Review. 28 (5), pp: 508-524. 
Dinata, S. Jovita, Srikandi Kumadji, dan Kadarisman Hidayat. 2014. Country Of Origin dan Pengaruhnya Terhadap Persepsi Kualitas dan Minat Beli (Survei pada Calon Konsumen yang Berminat Membeli iPad di Indonesia). Jurnal Administrasi Bisnis, Vol. 25, No.1. Agustusus 2015, pp.1-8.

Evelina, N., Wiratno dan S. Listyorini. 2012. Pengaruh Citra Merek, Kualitas Produk, Harga, dan Promosi Terhadap Keputusan Pembelian Kartu Perdana Telkom Flexi. Fakultas Ilmu Sosial dan Ilmu Politik, Jurusan Administrasi Bisnis Universitas Diponegoro, Semarang.

Fristiana, 2012. “ Pengaruh citra merek dan harga terhadap keputusan pembelian pada ramai swalayan peterongan semarang.

Hanzaee, K.H. and Khosrozadeh, S. 2011. The Effect of the Country-of-Origin Image, Product Knowledge and Product Involvement on Information Search and Purchase Intention. Middle-East Journal of Scientific Research, 8(3), pp: 625-636.

Hijir, P. (2015). Efek Customer Interaction Terhadap Satisfaction dan Word of Mouth Pada Hotel Mandarin Oriental. Jurnal Manajemen dan Pemasaran Jasa, 8(2), 101-114.

Kotler, P., and Armstrong, G. (2015). Marketing An Introducing Prentice Hall Twelfth Edition. England: Pearson Education Inc.

Keller, K. L. (2008). Strategic Brand Management - Building, Measuring and Managing Brand Equity Third Edition. New Jersey: Pearson Education International.

Kusuma, Separsa. IB dan Suparna, Gede. 2015. Peran gaya hidup dalam memediasi pengaruh demografi terhadap niat beli sepeda motor vespa piaggio E-Jurnal Manajemen Unud, Vol. 4, No. 8, 2015 : 2110-2124

Li, X., J.Yang, X. Wang, D. Lei. 2012.” The Impact of Country-of-origin Image, Consumer Ethenocentrism and Animosity on Purchase Intention”. Journal of Sofware Academy Publisher,7(10)

Lee, J. K., and Lee, W. N. 2009. Country-of-Origin Effects on Consumer Product Evaluation and Purchase Intention: The Role of Objective Versus Subjective Knowledge. Journal of International Consumer Marketing, 21(2), pp: 137151

Maunaza, A. 2012. "Pengaruh Brand image terhadap Niat Membeli Konsumen (Studi Pada Penerbangan Lion Air Sebagai Low Cost Carrier)". Skripsi Fakultas Ilmu Sosial Dan Ilmu Politik Program Studi Ilmu Administrasi Niaga Depok. 
Moksaoka, I Made Weli dan I Ketut Rahyuda. 2016. Peran Brand Image dalam Memediasi Country Of Origin Terhadap Purchase Intention. E-Jurnal. Manajemen Unud. Vol. 5, No. 3. Pp: 1690-1716.

Nasermoadeli, A., Ling, K. C., and Maghnati, F. (2013). Evaluating the Impacts of Customer Experience on Purchase Intention. International Journal of Business and Management, 8(6), 128-138.

Olson, J, C., \& Paul, P. J. (2014). Perilaku Konsumen dan Strategi Pemasaran. Edisi Sembilan.

Rangkuti, F. (2015). Analisis Swot : Teknik Membedah Kasus Bisnis. Cetakan ke-23. Jakarta: PT. Gramedia Pustaka Utama.

Rahyuda, Ketut. 2004. Buku Ajar Metodelogi Penelitian. Denpasar: Fakultas Ekonomi Universitas Udayana

Rezvani, S., Dehkordi, G.J., Rahman, M.S., Fouladivandal, F., Eghtebasi, S., and Habibi, M. (2012). A Conceptual Study on the Country of Origin Effect on Consumer Purchase Intention. Asian Social Science, 8(12), pp: 205-215.

Riduwan \& Kuncoro. 2011. Cara Menggunakan dan Memakai Path Analysis (Analisis Jalur). Bandung: Alfabeta

Rizan, Mohammad, Basrah Saidani dan Yusiyana Sari. 2012. Pengaruh Brand image dan Brand trust Terhadap Brand Loyalty The Botol Sosro Survei Konsumen The Botol Sosro di Food Court ITC Cempaka Mas, Jakarta Timur. Jurnal Riset Manajemen Sains Indonesia Indonesia (JRMSI), 3(01), pp:1-17.

Schiffman, Leon G, dan Leslie Lazar. 2008. Consumer Behavior. New Jersey: Prentice Hall.

Sugiyono. (2009). Metode Penelitian Bisnis (Pendekatan Kuantitatif, Kualitatif, dan $R \& D)$. Bandung: Alfabeta.

Suria, Nurina Nadhifi, Andriani Kusumawati, Dan Edriana Pangestuti. 2016. Pengaruh Country Of Origin Terhadap Citra Merek Dan Dampaknya Bagi Keputusan Pembelian. Jurnal Administrasi Bisnis. Vol 38. No.1.

Suprapti, Ni Wayan Sri. 2010. Prilaku Konsumen, Pemahaman Dasar dan Aplikasinya Dalam Strategi Pemasaran. Udayana University Press.

Tati, Putri Wahyu., Suharyono., dan Edy Yulianto. 2015. Pengaruh Country of Origin dan Global Brand Image Terhadap Minat Beli dan Keputusan 
Pembelian (Survei pada Konsumen yang Membeli Smartphone Samsung Galaxy di Asia Tenggara). Jurnal Administrasi Bisnis (JAB), 25(1), pp: 1-10

Tetanoe, V. R., \& Dharmayanti, D. (2014). Pengaruh Experiential Marketing Terhadap Pembelian Ulang Dengan Kepuasan Pelanggan Sebagai Variable Intervening di Breadtalk Surabaya Town Square. Jurnal Manajemen Pemasaran Petra, 2(1), 1-12.

Tulipa, Diyah and Ninuk Muljani. 2015. The Country of Origin and Brand Image Effect on Purchase Intention of Smarthphone in Surabaya-Indonesia. Mediterranean Journal of Social Sciences, 6(5), pp: 64-70

Yanthi, Pratita dan Jatra. 2015. Pengaruh Country of Origin, Brand Image, dan Perceived Quality Terhadap Minat Beli Sepeda Motor Honda Beat Di Kota Denpasar. E-Jurnal Manajemen Unud, 4(11), pp: 3852-3881 